\title{
Språklig feil som fungerer
}

\author{
Noen ganger er apostrofen \\ oppklarende.
}

Jeg er polsk innflytter med over 25 års botid her i landet. Jeg kan en del norsk, men føler meg aldri utlært. Jeg leste derfor Språkspalten i Tidsskriftet nr. 5/ 2011 om genitivs-s med stor interesse (1).

Som forholdsvis godt språkutdannet ga jeg fra starten av et språklig korrekt navn til min praksis: Dr. Sypulas spesialistkontor - uten apostrof. Effekten ble at jeg ofte hørte innfødte nordmenn omtale meg som dr. Sypulas. Det var irriterende for en som heter kun Sypula. Jeg forsøkte derfor å skifte skrivemåte til Dr. Sypula's spesialistkontor - med apostrof. Det fungerer! Ingen kaller meg Sypulas lenger. Kan det være mulig at man i norsk på sikt vil godta feil og bruke apostrof i genitiv som fast regel?

De fleste nordmenn mener sikkert at etternavnet mitt må være Wlodzimierz, ettersom det har flere bokstaver enn Sypula. Jeg finner meg sjelden under s i listene. Wlodzimierz brukes i hjemlandet mitt kun i offisielle sammenhenger. Alle som kan polsk, et land der det for øvig praktisk talt ikke finnes dialekter blant 40 millioner innbyggere, bruker automatisk Wlodek. Men folk som ikke kjenner meg, bør si Pan (herr) Wlodek. Det oppfattes som meget uhøflig å rope kun Wlodek. Eldre pasienter her i landet bruker ofte tiltaleformen De til meg. I Polen er dette fremdeles påkrevd.

\section{Wlodzimierz Sypula \\ dr.sypula@hotmail.com \\ Steffens vei 7}

1608 Fredrikstad

Litteratur
1. Hem E. Homans' tegn og Simmonds' syndrom. Tidsskr Nor Legeforen 2011; 131: 487. 


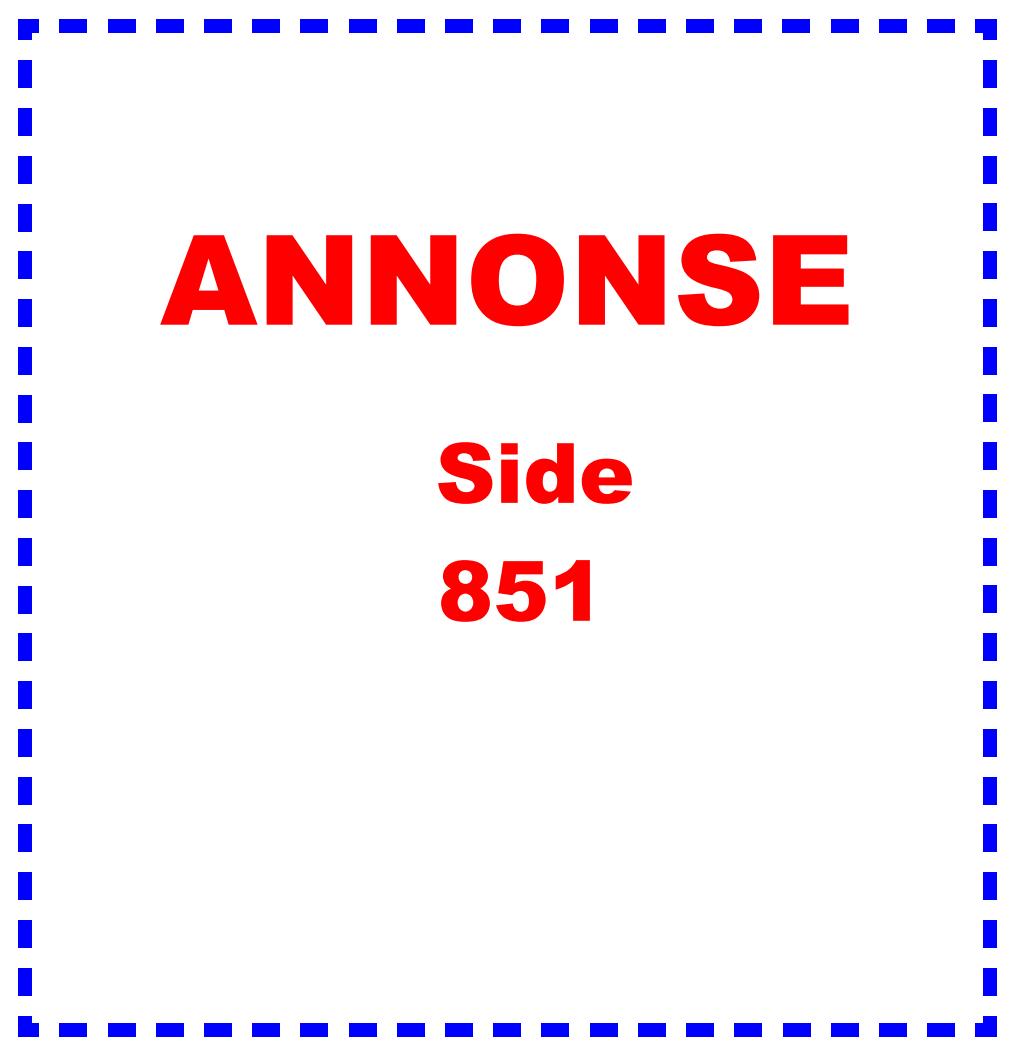

